\section{CARCINOMA OF THE STOMACH} AN EVALUATION OF DIAGNOSTIC METHODS INCLUDING EXFOLIATIVE CYTOLOGY

BY

W. BURNETT, Ch.M., F.R.C.S.

P. S. MACFARLANE, M.B., M.R.C.P.Ed.

S. D. SCOTT PARK, M.D., F.F.R., D.M.R.E. AND

A. W. KAY,* M.D., Ch.M.

Departments of Surgery, Pathology, and Radiology, The University and Western Infirmary, Glasgow

[With Special Plate]

Carcinoma of the stomach is often not diagnosed until the growth has reached an inoperable stage. In recent years there has been renewed interest in the study of exfoliated cells from gastric tumours in an attempt to make the diagnosis earlier than is possible by conventional methods (Papanicolaou, 1946; Swarts et al., 1950 ; Lemon, 1952; Rubin et al., 1953). In Great Britain Schade (1958) has diagnosed carcinoma of the stomach on 25 occasions when both barium-meal and gastroscopic findings were still negative. Stimulated by this work, we have evaluated the various diagnostic methods suitable for out-patient study, and in this report we present the results, referring particularly to the use of exfoliative cytology as a supplement to radiology and gastroscopy.

\section{Design of the Investigation}

All patients seen in the out-patient clinics of two surgical units over a period of nine months were included in the series if there was clinical suspicion of carcinoma of the stomach. The series includes a number of patients known to have a gastric ulcer but whose recent symptoms suggested the possible development of carcinoma. A barium-meal examination was first carried out. and so far as was possible all radiology in the series was performed by one person, who was aware only of the provisional clinical diagnosis. If the barium studies revealed no contraindication gastroscopy was then carried out, again so far as possible by one person who did not have access to the case record or the bariummeal report at the time of gastroscopy. Material for cytological examination was obtained immediately before gastroscopy. The patient fasted for at least 10 hours before the examination (if any evidence of pyloric obstruction was present the stomach was washed out through a wide-bore tube on the evening before the test). The method used was essentially similar to that described by Schade (1958). No mucolytic or abrasive methods were used to obtain cytological specimens. A No. 14 Levine tube was introduced through the mouth into the stomach, and $100 \mathrm{ml}$. of normal saline solution was injected by means of a rubber urethral syringe ( $2 \mathrm{oz} ; 57 \mathrm{ml}$.). The stomach was then evacuated as completely as possible, using a suction apparatus. In a very few cases, to facilitate insertion of the tube, the patient drank a glass of tap-water ; the injection of the $100 \mathrm{ml}$. of saline was omitted in these cases, and the water and stomach contents were evacuated. Either of these aspirates constituted the first specimen. A further

*Present address: University Department of Singery, Royal Infirmary, Sheffield.
$100 \mathrm{ml}$. of saline was injected into the stomach, and partially withdrawn and forcibly reinjected several times. The tube was then clamped, the patient instructed to lie in turn in the prone, supine, and lateral positions, to sit up, and finally to walk if ambulatory. The stomach was then aspirated to obtain the second specimen. Buth specimens were lightly centrifuged immediately, the sediment smeared on glass slides, and then stained by Papanicolaou's method. The cytologist did not have access to the radiological or gastroscopic findings.

The surgeon responsible for each patient decided for or against operation by reviewing the clinical, radiological, and gastroscopic evidence. The cytopathological report was consulted only on occasions when a decision was made against operation because of negative radiological and gastroscopic reports or when an apparently normal stomach was found at operation. If gastrectomy was performed, the resected specimen was immediately fixed for subsequent histological studies.

\section{Results}

Sixty-eight patients were thought to have a possible gastric carcinoma when first seen. This diagnosis was finally confirmed histologically in $24(35.3 \%)$. The age and sex distribution are shown in Table I. Radical resection was carried out in 12 of the 24 patients with carcinoma; in at least two of these the lesion was probably beyond the scope of surgery though it was resectable. A palliative resection was done in 5 , and no treatment was possible in 7.

Of the remaining 44 patients, $38155.9 \%$ of the total series) were found to have non-malignant conditions, and in $6(8.8 \%)$, whose gastric symptoms were of brief

TABLe I.-Age and Sex Distribution in 68 Cases in Which
Carcinoma of Stomach was Suspected on Clinical Grounds
\begin{tabular}{c|c|c|c|c} 
Age & No. of & \multicolumn{2}{|c}{ Patients with Carcinoma } \\
$\begin{array}{c}\text { Group } \\
\text { (Years) }\end{array}$ & $\begin{array}{c}\text { Natients } \\
\text { Pand }\end{array}$ & Male & Female & Total \\
\hline $30-39$ & 5 & 1 & 0 & 1 \\
$40-49$ & 10 & 1 & 0 & 1 \\
$50-59$ & 22 & 5 & 2 & 7 \\
$60-69$ & 20 & 7 & 5 & 12 \\
$70-79$ & 10 & 0 & 3 & 3 \\
$80-89$ & 1 & 0 & 0 & 0 \\
\hline Total & 68 & 14 & 10 & 24 \\
\hline
\end{tabular}

TABLB II-Final Diasnosis in 68 Patients Suspected Originally to Have Gastric Carcinoma

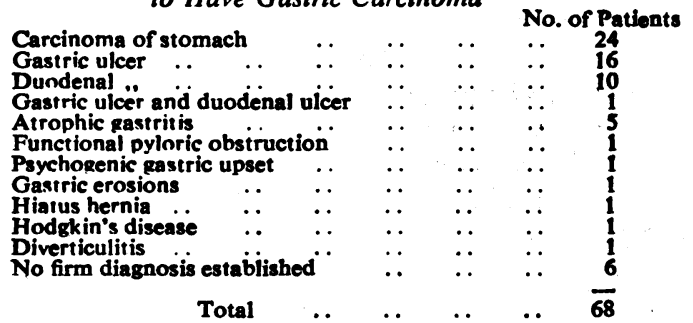

TABLB III.-Carcinoma of Stomach: Comparison of Results of Three Diagnostic Methods

\begin{tabular}{|c|c|c|c|}
\hline & Radiology & Gastroscopy & Cytolosy \\
\hline $\begin{array}{l}\text { A. Entire series }(68): \\
\text { Total investigated } \\
\text { fälures } \quad \ldots \\
\text { Falso-positive carcinoma } . .\end{array}$ & $\begin{array}{r}68 \\
0 \\
0\end{array}$ & $\begin{array}{r}64 \\
8 \\
2\end{array}$ & $\begin{array}{r}68 \\
5 \\
1\end{array}$ \\
\hline 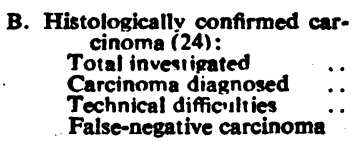 & $\begin{array}{l}24 \\
23(96 \%) \\
1(4 \%)\end{array}$ & $\begin{array}{l}22 \\
17(78 \%) \\
3 \\
2(9 \%)\end{array}$ & $\begin{array}{l}24 \\
13(54 \%) \\
29(38 \%)\end{array}$ \\
\hline
\end{tabular}


duration and abated spontaneously, no firm diagnosis was reached (Table II). The results obtained from radiology, gastroscopy, and cytology are compared in Table III.

\section{Radiology}

Barium-meal examination was carried out in all 68 patients. It was definite or suggestive of carcinoma in $23(96 \%)$ of the 24 patients who were found to have a histologically confirmed carcinoma. The one falsenegative result is discussed below (Case 34). In most cases the reports were unequivocal-for example, " constant filling defect, suggestive of carcinoma"; " high ulcer in the subfundic area, gastric carcinoma." In the non-malignant group no definite opinion which was shown to be a false positive was given. However, the radiologist expressed doubt as to the appearances on five occasions. A summary of these patients is given in Table IV.

TABLB IV.-Carcinoma of Stomach: Findings in Five Patients With Suspicious Radiological Appearances

\begin{tabular}{|c|c|c|c|c|}
\hline $\begin{array}{l}\text { Case } \\
\text { No. }\end{array}$ & Radiology & $\begin{array}{l}\text { Gastro- } \\
\text { scopy }\end{array}$ & Cytology & $\begin{array}{l}\text { Final } \\
\text { Diagnosis }\end{array}$ \\
\hline 11 & $\begin{array}{l}\text { Slight deformity lesser } \\
\text { curvature, also duo- } \\
\text { denal ulcer }\end{array}$ & Normal & $\begin{array}{l}\text { No malignant } \\
\text { cells seen }\end{array}$ & $\begin{array}{c}\text { Duodenal } \\
\text { ulcer }\end{array}$ \\
\hline 15 & $\begin{array}{l}\text { Narrowing of antrum: } \\
\text { ? disuse after gastro- } \\
\text { jejunostomy or? car- } \\
\text { cinoma }\end{array}$ & $\begin{array}{l}\text { Sovere } \\
\text { atrophic } \\
\text { gastritis }\end{array}$ & " & $\begin{array}{l}\text { Atrophic } \\
\text { gastritis }\end{array}$ \\
\hline 21 & $\begin{array}{l}\text { Irregularity +induration } \\
\text { of lesser curvature }\end{array}$ & Normal & $\begin{array}{l}\text { (1) Pro-opera- } \\
\text { tive: } \\
\text { highly } \\
\text { suggestive } \\
\text { of car- } \\
\text { cinoma ; } \\
\text { (2) Post-opera- } \\
\text { tion: } \\
\text { normal }\end{array}$ & $\begin{array}{l}\text { Nil found at } \\
\text { laparot- } \\
\text { omy }\end{array}$ \\
\hline 32 & $\begin{array}{l}\text { Possibility of carcinoma } \\
\text { raised in patient with } \\
\text { hiatus hernis }\end{array}$ & " & $\begin{array}{l}\text { No malignant } \\
\text { cells seen }\end{array}$ & $\underset{\text { hernia }}{\text { Hiatus }}$ \\
\hline 64 & $\begin{array}{l}\text { Hour-glass constriction } \\
\text { at mid-gastric level }\end{array}$ & $\begin{array}{l}\text { Failed; } \\
\text { gastroscope } \\
\text { arrested at } \\
\text { cardia }\end{array}$ & " & $\begin{array}{c}\text { Healing } \\
\text { gastric } \\
\text { ulcer }\end{array}$ \\
\hline
\end{tabular}

A malignant lesion was excluded by gastroscopy in four of the five cases. Gastroscopy failed in Case 64, a woman aged 69 who did not wish to be operated on, but a healing gastric ulcer was subsequently demonstrated radiologically. Cytological reports were similarly negative for carcinoma in four of the five cases in the group. In Case 21 (discussed below) the report, which suggested carcinoma, was shown to be misleading.

\section{Gastroscopy}

This was attempted in 64 of the 68 patients. It was not done in the remaining four either because of the refusal of the patient or because of the presence of an organic impediment to the passage of the tube-for example, an oesophageal diverticulum. Gastroscopy was carried out in 22 of 24 patients who were proved to have gastric carcinoma; a suspicious lesion or a definite carcinoma was seen in $17(78 \%)$; the examination was incomplete or failed in three cases, but failure was suspected as being due to the presence of a large carcinoma, and this was later confirmed. Two falsenegative results were obtained. In one, a patient shown at laparotomy to have an inoperable pyloric carcinoma, evidence of pyloric stenosis was found but no carcinoma. The other case in which a carcinoma was not seen is discussed below (Case 34).

In the remainder of the series (those with no proved gastric carcinoma) gastroscopy produced two falsepositive results.
Case 13.-A lesion thought to be a carcinoma was seen at gastroscopy in a patient in whom barium-meal findings and cytology were normal. No carcinoma .was found at operation, when the lesion was seen to be a duodenal ulcer a repeat gastroscopy five months later was negative.

Case 26.-A large ulcer proximal to the angularis was thought to be malignant. Barium-meal examination showed a benign ulcer, and cytology was negative for malignant cells. At operation it proved difficult to decide whether the ulcer was benign or malignant, but histological examination after gastrectomy proved the ulcer to be benign.

In neither case did gastroscopy alter the treatment, as laparotomy was required in Case 13 on clinical grounds and gastrectomy was necessary in Case 26.

\section{Exfoliative Cytology}

This was attempted in all 68 patients in the series. It was unsuccessful in five owing to failure to obtain the specimen, insufficient material, or lack of cooperation by the patient. Cells described as suspicious or definitely malignant were found in $13(54.2 \%)$ out of 24 patients who had a proved carcinoma. In one of them (Case 34) barium-meal examination and gastroscopy had been negative; comparison and correlation of the histological preparations and smears of the gastric washings proved interesting and instructive in the positive cases (Special Plate, Figs. 1-4). In two cases $(8.5 \%)$ the material was found to be unsuitable for diagnosis; nine $(37.5 \%)$ false negatives were obtained. Barium-meal findings were positive or highly suggestive in all nine, and gastroscopy was positive in six and suspected in two of the eight cases in which it was carried out. In all nine cases the lesion was a huge carcinoma which was fungating or ulcerating; three of the nine were inoperable, and in three others total gastrectomy was required with removal of other near-by structures-pancreas, colon, etc. Histological examination of the tumour when exfoliative cytology was negative showed an anaplastic carcinoma in four cases and poorly differentiated adenocarcinoma in four.

Only one apparently false-positive result (Case 21) was obtained, in a patient who has not so far been shown to have a carcinoma. In a reappraisal of the slides in this case it is clear that the report which indicated the presence of "cells highly suspicious of malignancy" was too strongly worded. The explanation of this mistake probably lies in the fact that this case occurred early in the series when the cytologist had insufficient experience of the appearances with the new technique.

\section{Illustrative Cases}

\section{Case 34}

This patient, a woman aged 59 , had complained of vague indigestion for a number of years ; in the two months before being seen she had anorexia and generalized weakness. Barium-meal examination was negative ; gastroscopy showed general atrophy of the mucosa and diminished movement in the pyloric antrum, but no evidence of carcinoma. Cytopathology showed a single clump of malignant cells (Special Plate, Fig. 5). At laparotomy, which included gastrotomy, no carcinoma was found, but a high partial gastrectomy was carried out because of the cytological report. Examination of the resected specimen showed general mucosal atrophy. There were two small $(6 \mathrm{~mm}$. diameter) domeshaped swellings in the mucosa of the anterior wall just below the lesser curvature 1 and $2 \mathrm{~cm}$. from the pylorus respectively. Microscopical examination confirmed the presence of atrophic gastritis. The small papillary lesion (Special Plate, Fig. 6) showed acinar dedifferentiation and 
increased mitotic activity (Special Plate, Fig. 7), and was considered to be a very early carcinoma.

The long clinical history was probably due to atrophic gastritis with a recent exacerbation. The minute carcinoma could scarcely have been responsible for any clinical symptoms, but would have been missed in an early operable state but for the use of cytopathology. The patient has remained well for 15 months since the operation. She has a good appetite, and her pre-operative gastric symptoms have not recurred.

\section{Case 21}

This patient, a woman aged 30 , had a three-months history of anorexia, nausea, and abdominal discomfort. She had lost a stone $(6.4 \mathrm{~kg}$.) in weight in nine months. Bariummeal examination showed irregularity of the lesser curvature a little below the cardia; the contour was constant and seemed indurated. At gastroscopy the stomach appeared normal. Cytological examination showed cells highly suggestive of malignancy. At laparotomy no carcinoma or other abnormality was found; at gastrotomy the gastric mucosa was of the thickened, rugose variety but otherwise normal. A biopsy of glands from the lesser and greater curvatures revealed only catarrhal changes. The operator did not feel justified in proceeding to gastrectomy. A repeat cytological examination was carried out in the convalescent period, and on this occasion no malignant cells were seen. Radiological examination five months later showed giant-type folds in the upper part of the body of the stomach, but no other abnormality was demonstrated. This patient has now been followed up for nine months, and carcinoma has not developed.

\section{Comment}

The results given above again demonstrate that one patient in every two reaches hospital after the gastric carcinoma is inoperable. It is also clear that diagnosis is often all too easy on clinical grounds at the time of the first visit to the surgical out-patient clinic. However, we have been impressed with the value of the conventional aids to diagnosis. Barium-meal examination disclosed all the malignant lesions found in the series except one very small carcinoma (Case 34). Gastroscopy proved a valuable adjunct to radiology, particularly in the study of gastric ulcer and the demonstration of gastritis and erosions, and in those cases where radiology had raised some doubt whether the stomach was clear of carcinoma. In all cases except one (Case 34) these two examinations proved to be an efficient diagnostic screen.

At first glance the results of exfoliative cytology are disappointing. Carcinoma was diagnosed in only $54 \%$, but the nine false-negative cases $(38 \%)$ all occurred in patients with a large ulcerating tumour-where the diagnosis was already clear by the other methods. False-negative results in this type of case have been described by Lemon (1952) and Schade (1958), and may well be due to a layer of necrotic cells on the surface of the tumour (Umiker et al., 1958).

A false-negative rate of $50 \%$ seems to be not uncommon (Swarts et al., 1950 ; Lemon, 1952). Indeed, Papanicolaou and his co-workers believe that, if ideal multiple specimens are obtained and properly handled, accuracy of $60 \%$ is about the limit (Seybolt et al., 1951). In an effort to raise this percentage, various mucolytic and abrasive substances have been used to improve the material obtained from gastric washings (Panico et al., 1950 : Rosenthal and Traut, 1951 ; Ayre and Oren, 1953 ; Van der Reis et al., 1956; Cooper and Papanicolaou, 1953 ; Crozier et al., 1956). However, there is no general agreement that the use of these methods has substantially increased the accuracy possible.

In our series this method was at a disadvantage in that, though the cytologist had had considerable experience with specimens of sputum and from the respiratory tract, he had not previously dealt with gastric washings. Nevertheless, one very early carcinoma has been demonstrated when other methods could not have succeeded. This compares with Schade's (1958) demonstration of one such case per 100 examinations, and we agree with him that exfoliative cytology is a potentially valuable diagnostic procedure in the investigation of such an important disease as carcinoma of the stomach, where early diagnosis even in a small percentage of cases is an advance.

We suggest that the results of our investigation indicate that exfoliative cytology is a valuable supplement to radiology and gastroscopy, and logically should be used in clinically suspicious cases when these latter methods prove negative. It is certainly not a good screening procedure. We further suggest that the method should be available as a part of a cytology service in the larger centres, since we believe that it has clinical value and is not economically wasteful, provided that its use is confined to judiciously selected cases, and, in particular, that the temptation to use it as a routine screening procedure is resisted.

\section{Summary}

A method suited to the evaluation of radiology, gastroscopy, and exfoliative cytology in the diagnosis of carcinoma of the stomach is described. Our results show that the combined use of radiology and gastroscopy provides a reliable diagnostic screening method.

In a series of 68 patients, exfoliative cytology revealed one early case of carcinoma of the stomach which the other methods could not have been expected to detect. Cytology is therefore a valuable adjunct when the routine methods give negative results in clinically suspicious cases.

The high incidence of false-negative results (38\%) shows exfoliative cytology to be an unreliable screening test for carcinoma of the stomach.

Our thanks are due to our clinical colleagues, Professor C. F. W. Illingworth, Mr. D. H. Clark, and Mr. A. P. M. Forrest, for their willing co-operation and for allowing us to include their cases in the series. P.S. M. is grateful to Mr. Carrick Henderson for his technical help in the cytological investigation, and to Mr. George Kerr for the photographs.

\section{REFERENCES}

Ayre, J. E., and Oren, B. G. (1953). Cancer, 6, 1177.

Cooper, W. A., and Papanicolaou, G. N. (1953). J. Amer. med.

Crozier, R. E., Middleton, M., and Ross, J. R. (1956). New Engl. J. Med. 255, I128.

Lemon, H. M. (1952). Ann. intern. Med., 37, 525

Panico, F. G., Papanicolaou, G. N., and Cooper, W. A. (1950). J. Amer. med. Ass., 143,1308

Papanicolaou, G. N. (1946). Ibid., 131, 372.

Rosenthal, M., and Traut, H. F. (1951). Cancer, 4, 147.

Rubin, C. E., Massey, B. W., Kirsner, J. B., Palmer, W. L., and Stonecypher, D. D. (1953)). Gastroenterology, 25, 119.

Schade, R. O. K. (1958). Brit. med. J., 1, 743.

Seybolt. J. F., Papanicolaou, G. N., and Cooper, W. A. (1951). Cancer 4,286 .

Swarts, J. M.. Ragins, A. B., Bernstein, A., and Meyer, J. (1950). Gastruenterology. 1f, 265

Umiker, W. O., Bolt. R. J., Hoekzema, A. D., and Pollard, H. M. (1958). Ihid., 34. 859.

Van der Reis, L., Rider, J. A., and Frost, J. K. (1956). Amer. J. med. Sci., 231, 249. 


\section{W. BURNETT ET AL.: CARCINOMA OF STOMACH}

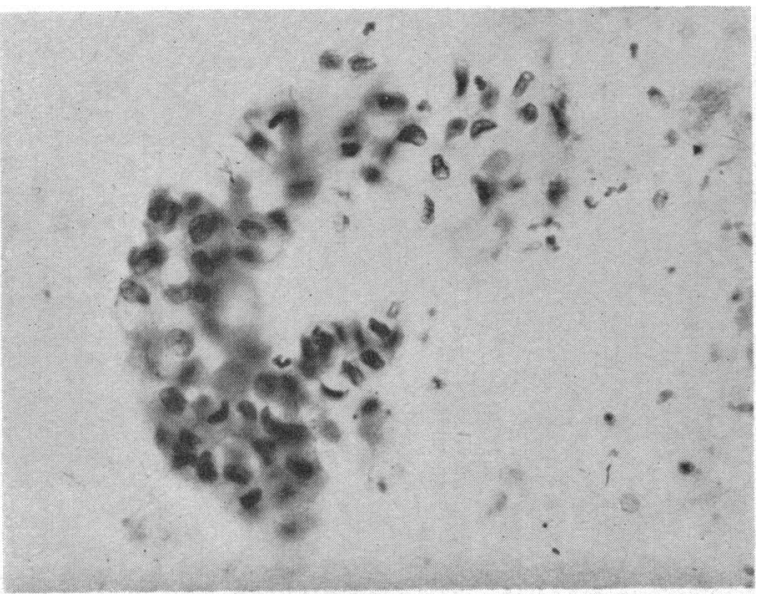

FIG. 1.-Typical clump of malignant cells present in a smear. (Papanicolaou and H. and E. $\times 296$.)

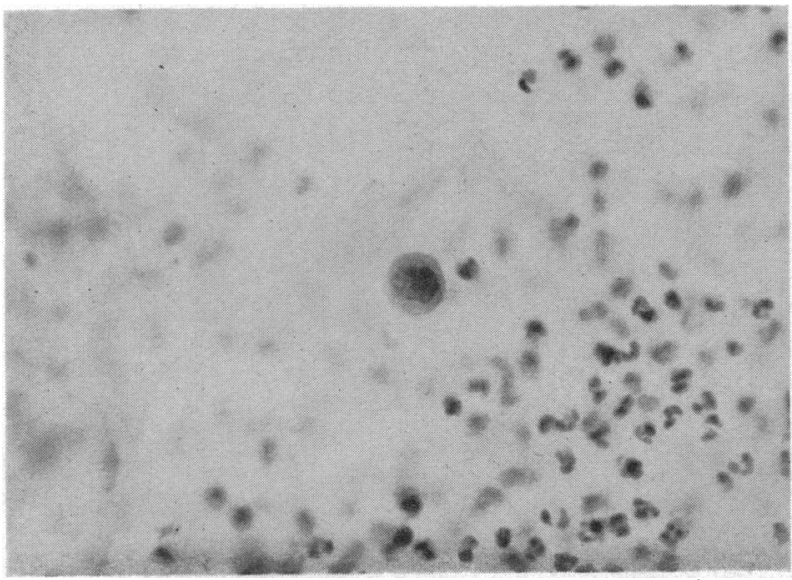

Fig. 3.-Single malignant cells found in a smear. (Papanicolaou and $H$, and $E$. $\times 296$.)

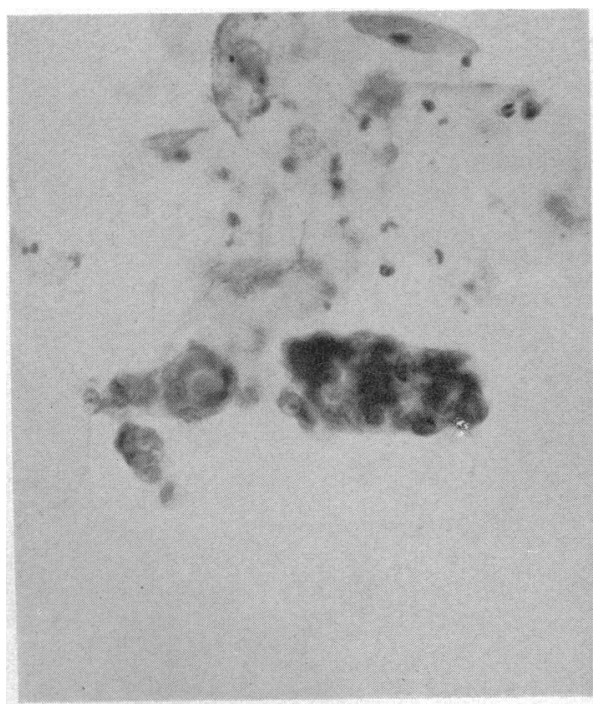

FIG. 5

Fio. 5.-Clump of malignant cells seen in a smear obtained from Case 34. (Papanicolaou. $\times 296$.)

Fig. 6.- Small sessile mucosal outgrowth found in gastrectomy specimen from Case 34 (H. and E. $\times 6$.)

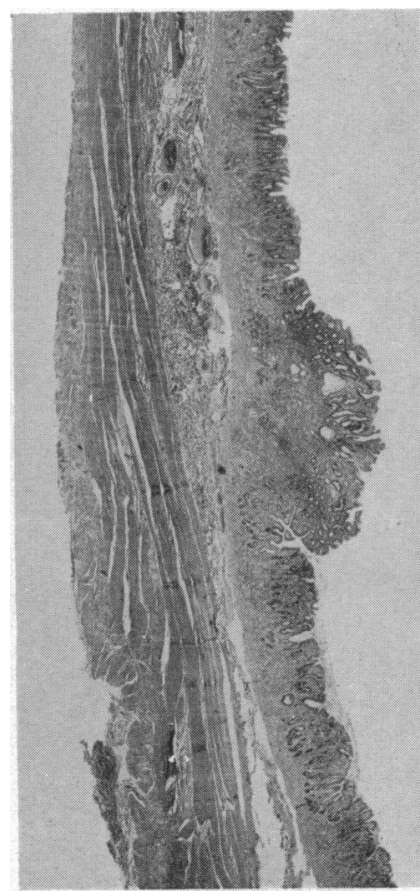

Fio. 6

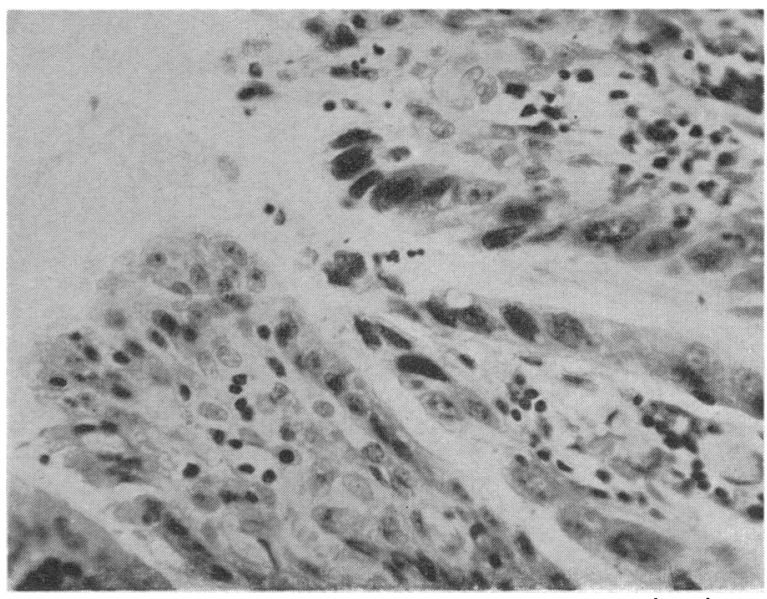

FIG. 2.-Surface of tumour from which cells shown in Fig. 1 were shed. (Papanicolaou and H. and E. $\times 296$.)

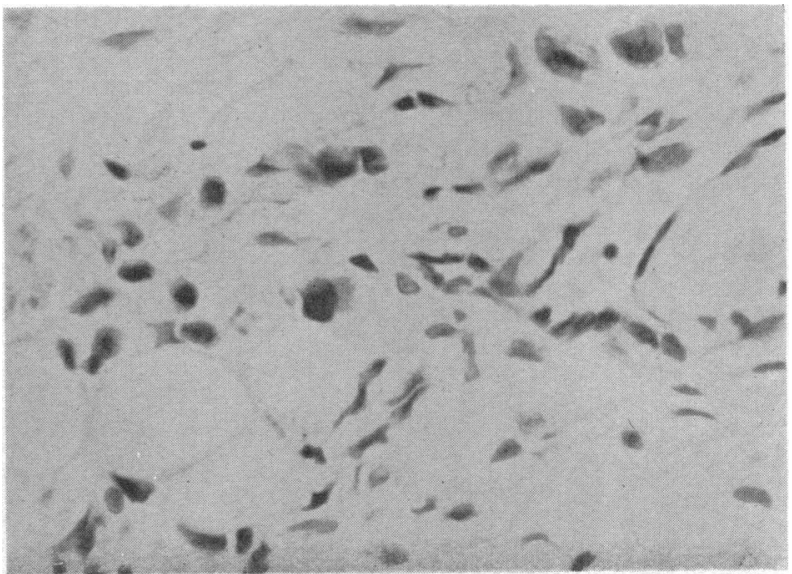

Fig. 4.-Infiltration of peritoneal fat by single carcinoma cells as seen in a biopsy from same case as Fig. 3. (Papanicolaou and $H$. and $E$. $\times 296$.)

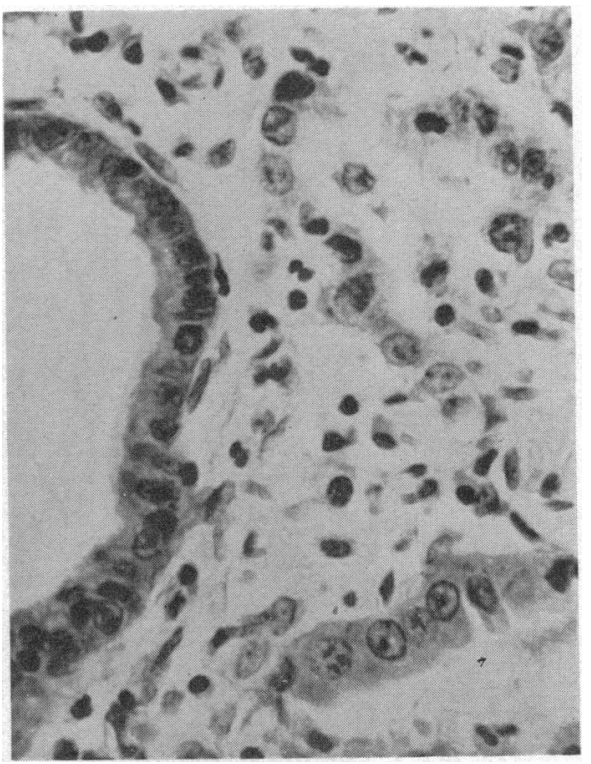

Fro. 7.-High-power field in papillary lesion of Case 34. Epithelial cells lining acini show dedifferentiation and mitotic activity. Malignant epithelial cells are infiltrating stroma (upper right). (H. and E. $\times 525$.) 